\title{
ANALISIS KESEHATAN KEUANGAN PERUSAHAAN DI MASA PANDEMI COVID 19 MENGGUNAKAN RASIO LIKUIDITAS, PROFITABILITAS DAN SOLVABILITAS (STUDI KASUS UMKM AMEERA HIJAB)
}

\author{
Agus Dwi Cahya ${ }^{1}$, Heditri Rachmawati ${ }^{2}$, Rista Ridhowasti ${ }^{3}$ \\ 1,2,3Program Studi Manajemen, Fakultas Ekonomi, Universitas Sarjanawiyata Tamansiswa, \\ Yogyakarta, Indonesia \\ putrirista43@gmail.com
}

\begin{abstract}
Abstrak
Pada penelitian ini dimaksudkan untuk menganalisis rasio likuiditas perusahaan (X1), rasio profitabilitas perusahaan (X2) dan rasio solvabilitas perusahaan (X3) untuk mengukur kesehatan keuangan perusahaan (Y). Penelitian ini merupakan penelitian kuantitatif dengan metode analisis data. Pemilihan sampel penelitian ditentukan berdasarkan tujuan penelitian yaitu untuk mengetahui kesehatan keuangan UMKM Ameera Hijab di masa pandemi Covid-19 sehingga populasi dan sampel pada penelitian adalah UMKM "Ameera Hijab" yang berlokasi di jalan Parangtritis No. 9 Druwo Bangunharjo Kecamatan Sewon, Kabupaten Bantul, Propinsi Daerah Istimewa Yogyakarta. Hasil penelitian menunjukkan bahwa kesehatan keuangan pada Ameera Hijab di masa pandemi dalam kondisi baik ditunjukkan dengan nilai rasio likuiditas sebesar tak terhingga, rasio profitabilitas sebesar 37\% dan rasio solvabilitas sebesar 0\%.
\end{abstract}

Kata Kunci: UMKM, likuiditas, profitabilitas, solvabilitas, dan kesehatan perusahaan

\begin{abstract}
The world's economy has been greatly affected by the Covid-19 pandemic, including in Indonesia and has had a strong influence on MSMEs including the "Ameera Hijab" MSME. This study is intended to analyze the company's liquidity ratio (X1), the company's profitability ratio (X2) and the company's solvency ratio (X3) to measure the company's financial health $(Y)$. This research is a quantitative research with data analysis method. The selection of research samples was determined based on the research objective, namely to determine the financial health of Ameera Hijab SMEs during the Covid-19 pandemic so that the population and sample in the study were "Ameera Hijab" SMEs located on Jalan Parangtritis No. 9 Druwo Bangunharjo, Sewon District, Bantul Regency, Special Region of Yogyakarta Province. The results showed that the financial health of Ameera Hijab during the pandemic was in good condition as indicated by the value of the liquidity ratio of infinity, the profitability ratio of $37 \%$ and the solvency ratio of $0 \%$.
\end{abstract}

Keywords: MSMEs, liquidity, profitability, solvency, and company health 


\section{PENDAHULUAN}

Pandemi Covid-19 masih terus menunjukkan keberadaannya di bergagai penjuru dunia bahkan hingga saat ini sama sekali belum juga terlihat tanda-tanda penurunan kasus terkonfirmasi Covid-19 yang signifikan. Bahkan hingga saat ini Pemerintah masih terus melakukan upaya penanganan dan pencegahan penularan Covid-19 dengan membuat kebijakan-kebijakan yang mampu mendukung upaya tersebut. Tak dapat kita pungkiri bahwa pandemi Covid-19 ini memberikan dampak yang luar biasa terhadap usaha perekonomian yang mengakibatkan banyaknya perusahaan yang dengan sangat terpaksa harus melakukan pemutusan hubungan kerja secara besar-besaran karena tidak mampu lagi menggaji karyawannya.

Kondisi inilah yang justru menjadi trigger terutama masyarakat kecil untuk dapat menciptakan ide kreatif demi tetap melanjutkan hidup. Karena mereka harus berusaha untuk menjaga kelangsungan hidup mereka tanpa mengharapkan belas kasihan dari pmemerintah. Banyak dari mereka yang mencoba menekuni dunia usaha kecil, mikro dan menengah dengan banyaknya UMKM yang bermunculan di sekitar lingkungan kita dengan ide kreatif dagang ataupun mengembangkan inovasi yang telah ada.

UMKM merupakan sebuah usaha kreatif ekoomi yang biasanya dijalankan oleh seorang atau kelompok orang

Mengutip dari berita seputar kondisi UMKM hijab pada masa pandemi pada lamam https://economy.okezone.com/ pada Minggu 04 Oktober 2020 19:19 WIB Mulyana Erlan penyelenggaran The Greta Hijab Fair mengatakan bahwa semangat yang dimiliki oleh penggiat UKM sungguh luar biasa. Bahkan di masa pandemi ini dijadikan sebagai momentum pembelajaran untuk terus berkarya dan berinovasi dengan mengikuti perkembangan tren fashion sehingga usahanya dapat tetap bertahan bahkan semakin terus berkembang.(Yuwono, 2020)

Menurut kutipan berita tersebut dapat disimpulkan bahwa UMKM hijab justru mengalami pertumbuhan dan perkembangan yang sangat baik dan hal ini menimbulkan ketertarikan penulis untuk melakukan penelitian terkait kondisi UMKM hijab pada masa pandemi saat ini untuk mencari pembuktian terkait hal tersebut. Untuk mengetahui sebuah UMKM tersebut mengalami pertumbuhan atau tidak maka perlu dilakukan adanya penelitian terhadap kesehatan keuangan pada sebuah perusahaan tersebut. Jika perusahaan tersebut dalam kondisi sehat maka bisa dikatakan bahwa perusahaan ataupun UMKM tersebut mengalami pertumbuhan dan memungkinkan untuk terus mengembangkan usahanya. Analisis yang akan dilakukan yakni analisis terkait rasio keuangan perusahaan tersebut karena mampu menggambarkan secara komprehensif tentang kondisi kesehatan keuangan dengan melihat kinerja keuangan pada perusahaan tersebut dalam kondisi likuid, profitabel dan solvabel. Jika sebuah perusahaan mempunyai tingkat likuiditas dan profitabilitas tinggi berarti hal ini menunjukkan bahwa kesehatan keuangan perusahaan tersebut dalam kondisi baik dimana perusahaan memiliki kemampuan yang sangat cukup untuk membayar atau melunasi kewajiban atau hutang perusahaan dikarena memiliki surpus cash yang tinggi sehingga tidak mengganggu atau menghambat jalannya manajemen di perusahaan. Serta tingkat solvabilitas yang rendah dimana perusahaan memiliki resiko yang lebih kecil terkait kemampuan perusahaan dalam memenuhi kewajiban atau total utang baik utang jangka panjang maupun utang jangka pendeknya.

\section{TINJAUAN PUSTAKA UMKM}

Usaha Mikro Kecil dan Menengah (UMKM) merupakan usaha yang dijalankan atau dilakukan oleh perseorangan secara mandiri ataupun oleh pihak atau badan usaha pada sektor ekonomi produktif kreatif yang memenuhi persyaratan dan kriteria yang telah ditentukan oleh pemerintah yang dituangkan kedalam Undang-undang Nomor 20 Tahun 2008.

Adapun UMKM dijabarkan sesuai kategori sebagai berikut :

1. Usaha mikro

Yang termasuk dalam kategori usaha mikro adalah usaha yang mempunyai kekayaan bersih paling banyak Rp.50.000.000,00. tidak termasuk tanah dan bangunan tempat usaha dan mempunyai hasil penjualan setiap tahunnya paling banyak Rp.300.000.000,00.

2. Usaha kecil

Yang termasuk dalam kategori usaha kecil adalah yang mempunyai kekayaan bersih lebih dari Rp.50.000.000,00 dan paling banyak mencapai Rp.500.000.000,00 tidak termasuk tanah dan bangunan tempat usaha dan mempunyai hasil penjualan setiap tahunnya lebih dari Rp300.000.000,00 dan paling banyak mencapai Rp2.500.000.000,00.

3. Usaha menengah

Yang termasuk dalam kategori usaha menengah adalah yang mempunyai kekayaan bersih lebih dari Rp.500.000.000,00 dan paling banyak mencapai Rp.10.000.000.000,00 tidak termasuk tanah dan bangunan tempat usaha dan mempunyai hasil penjualan setiap tahunnya lebih dari 
Rp2.500.000.000,00 dan paling banyak mencapai Rp50.000.000.000,00.

\section{Kesehatan Keuangan Perusahaan}

Tingkat kesehatan keuangan suatu perusahaan merupakan interpretasi dari prestasi kinerja keuangan perusahaan yang mencerminkan tentang baik atau tidaknya kondisi keuangan perusahaan tersebut. Untuk mengetahui nilai tingkat kesehatan keuangan perusahaan dapat dengan menggunakan analisis rasio keuangan.(Sari et al., 2019). Keuangan perusahaan dikatakan sehat saat nilai rasio keuangannya berada pada kondisi sebagai berikut:

1. Standar rasio industri yang harus dimiliki oleh suatu perusahaan untuk current ratio atau rasio lancar minimal adalah sebesar $200 \%$ atau 2 kali. (Dewi, 2017)

2. Standar rasio industri untuk ROA adalah sebesar 5,85\%. Apabila ROA lebih besar dari $5,85 \%$ berarti perusahaan tersebut mempunyai kemampuan menghasilkan profit yang baik. (Saefullah, 2018)

3. Standar rasio industri untuk debt to assets ratio atau rasio total utang terhadap total aset maksimal yang boleh dimiliki oleh suatu perusahaan adalah 35\%.(Dewi, 2017)

\section{Analisis Rasio Keuangan}

Analisis rasio keuangan merupakan teknis analisis terhadap laporan keuangan suatu perusahaan dengan menggunakan rasio-rasio keuangan. Rasio keuangan dapat dihitung dengan cara menggabungkan angka-angka yang terdapat pada neraca keuangan ataupun angka-angka yang terdapat pada laporan laba rugi suatu perusahaan. (Hanafi, 2016)

Penggunaan analisis rasio keuangan untuk menilai kinerja keuangan suatu perusahaan karena analisis rasio keuangan ini bersifat komprehensif atau teliti dalam penelitian dapat memperoleh hasil data yang akurat.(Apolonaris Felix Erakipia, 2016)

Pengukuran rasio keuangan menggunakan rasio likuiditas, rasio leverage, rasio aktivitas dan rasio profitabilitas mampu memberi gambaran mengenai kondisi perusahaan sehingga dapat dijadikan dasar dalam tindakan pengambilan kebijakan perusahaan. (Erica, 2018)

\section{Rasio Likuiditas}

Rasio ini untuk mengukur kemampuan likuiditas jangka pendek suatu perusahaan dengan membandingkan besarnya aktiva lancar terhadap utang lancarnya. (Hanafi, 2016)

Rumus:

$$
\text { Rasio Lancar }=\frac{\text { aktiva lancar }}{\text { utang lancar }}
$$

\section{Rasio Profitabilitas}

Rasio profitabilitas merupakan rasio keuangan yang digunakan untuk mengukur tingkat perolehan laba terhadap penjualan atau total aktiva pada periode tertentu. Salah satunya dapat menggunakan rasio return off asset (ROA).(Martina, 2019)

Rumus :

$$
\mathrm{ROA}=\frac{\mathrm{EBIT}}{\text { total aktiva }}
$$

\section{Rasio Solvabilitas}

Rasio ini digunakan untuk mengukur kemampuan suatu perusahaan dalam memenuhi kewajiban jangka panjang atau utang jangka panjangnya. Rasio ini dapat diperoleh dengan menghitung rasio utang terhadap asetnya. (Hanafi, 2016)

Rumus:

Rasio total utang terhadap total aset $=$ total utang total aset

\section{METODE}

Jenis penelitian yang dilakukan adalah penelitian kuantitatif dengan metode analisis data yang bertujuan untuk mengetahui kesehatan keuangan perusahaan pada sampel penelitian. Pemilihan sampel penelitian berdasarkan tujuan penelitian yaitu untuk mengetahui kesehatan keuangan UMKM Ameera Hijab sehingga populasi dan sampel pada penelitian ini adalah UMKM "Ameera Hijab" yang berlokasi di jalan Parangtritis No. 9 Druwo Bangunharjo Kecamatan Sewon, Kabupaten Bantul, Propinsi Daerah Istimewa Yogyakarta. Sumber data pada penelitian ini berupa data sekunder yang diperoleh dari subyek penelitian berupa laporan keuangan sederhana tahun 2020 untuk diolah oleh peneliti menjadi data berupa rasio yang selanjutnya dilakukan analisis perbandingan terhadap nilai standar rasio keuangan untuk sebuah perusahaan dikatakan sehat sehingga tingkat kesehatan keuangan pada sampel penelitian dapat diketahui. 


\section{HASIL DAN PEMBAHASAN}

\section{Hasil Penelitian}

Berikut data penelitian hasil olah data laporam keuangan dari UMKM Ameera Hijab :

Tabel 1

UMKM Ameera Hijab

Neraca Keuanngan

Per 31 Desembe 2020

\begin{tabular}{|c|c|c|c|c|}
\hline \multicolumn{3}{|c|}{ AKTIVA } & \multicolumn{2}{|l|}{ PASIVA } \\
\hline \multicolumn{3}{|l|}{ Aktiva Lancar } & \multicolumn{2}{|l|}{ Hutang Lancar } \\
\hline Kas Bank & & $10,500,000$ & Hutang Dagang & \\
\hline Persediaan & & $18,100,000$ & Hutang Bank & \\
\hline Piutang & & 750,000 & Hutang Lain & \\
\hline Perlengkapan Toko & & $2,500,000$ & & \\
\hline \multicolumn{2}{|c|}{ Jumlah Aktiva Lancar } & $31,850,000$ & & \\
\hline Aktiva Tetap & & & Hutang Jangka Panjang & \\
\hline Tanah & & $25,000,000$ & Hutang Bank & \\
\hline Bangunan & & $20,000,000$ & Hutang Investasi & \\
\hline Mes in & & $2,000,000$ & & \\
\hline Penyusutan & & $-200,000$ & & \\
\hline \multicolumn{2}{|c|}{ Jumlah Akitiva Tetap } & $46,800,000$ & Modal & \\
\hline & & & Modal & Rp $49,450,000$ \\
\hline & & & Laba & Rp 29,200,000 \\
\hline Jumlah Aktiva & & 78,650,000 & Jumlah Pasiva & Rp 78,650,000 \\
\hline
\end{tabular}

Sumber: data diolah Penulis (2021)

Tabel 2

UMKM Ameera Hijab

Laporan Laba Rugi

Per 31 Desember 2021

\begin{tabular}{|c|c|c|c|c|}
\hline Keterangan & & & \multicolumn{2}{|c|}{ Jumlah } \\
\hline Pendapatan & & & $\mathbf{R p}$ & $69,500,000$ \\
\hline 1. Penjualan Tunai & $\mathrm{Rp}$ & $69,000,000$ & & \\
\hline 2. Penjualan Kredit & $\mathrm{Rp}$ & 500,000 & & \\
\hline \multicolumn{5}{|l|}{ Pengeluaran } \\
\hline Biaya & & & $\mathbf{R p}$ & $40,300,000$ \\
\hline 1. Tenaga Kerja & $\mathrm{Rp}$ & $10,800,000$ & & \\
\hline 2. Modal Kerja & $\mathrm{Rp}$ & $18,000,000$ & & \\
\hline 3. Material & $\mathrm{Rp}$ & $7,000,000$ & & \\
\hline 4. Mesin dan energi & $\mathrm{Rp}$ & $2,500,000$ & & \\
\hline 5. Administrasi Umum & $\mathrm{Rp}$ & $2,000,000$ & & \\
\hline Laba & & & $\mathbf{R p}$ & $29,200,000$ \\
\hline
\end{tabular}

Sumber: data diolah Penulis (2021) 


\section{Nilai Rasio Keuangan}

Nilai rasio aktual, yakni:

Likuiditas

Rasio lancar $=\frac{\text { Rp. } 31,850,000}{\text { Rp. } 0} \times 100 \%=\infty$

Solvabilitas

Rasio total utang terhadap total aset

$$
=\frac{\text { Rp. } 0}{\text { Rp. } 78.650 .000} \times 100 \%=0 \%
$$

\section{Profitabilitas}

ROA $=\quad$ Rp. $29,200,000 \times 100 \%=37 \%$

Rp. 78,650,000

Nilai rasio standar yakni:

$\begin{array}{lll}\text { Likuiditas } & = & 200 \% \\ \text { Profitabilitas } & = & 5,85 \% \\ \text { Solvabilitas } & = & 35 \%\end{array}$

\section{Pembahasan}

\begin{tabular}{|l|c|c|c|c|}
\hline \multicolumn{1}{|c|}{ Item } & Standar & Aktual & Tinggi/ Rendah & $\begin{array}{c}\text { Kesehatan } \\
\text { Perusahaan }\end{array}$ \\
\hline Likuiditas (Current ratio) & $200 \%$ & $\infty$ & Tinggi & Baik \\
\hline Profitabilitas (ROA) & $5,85 \%$ & $37 \%$ & Tinggi & Baik \\
\hline $\begin{array}{l}\text { Solvabilitas (Debt to asset } \\
\text { ratio) }\end{array}$ & $35 \%$ & 0 & Rendah & Baik \\
\hline
\end{tabular}

Berdasarkan hasil perhitungan dapat dianalisis bahwa:

1. Rasio Likuiditas

Rasio likuiditas yang dimiliki UMKM "Ameera Hijab" pada tahun 2020 dengan menghitung nilai current ratio atau rasio lancar diperoleh nilai aktualnya sebesar tak terhingga dan lebih tinggi dari nilai standar yakni 200\% dikarenakan UMKM "Ameera Hijab" tidak memiliki kewajiban atau utang jangka pendek dalam pengelolaan usahanya hal ini bisa dikatakan bahwa UMKM "Ameera Hijab" mempunyai likuiditas tinggi atau likuid. Hal ini berarti sesuai dengan penelitian (Sari et al., 2019) bahwa jika sebuah perusahaan berada pada kondisi mampu untuk membayar kewajiban jangka pendeknya dimana aktiva lancar yang dimiliki oleh perusahaan tersebut mampu menutup kewajiban atau utang jangka maka perusahaan dalam keadaaan likuid,

2. Rasio Profitabilitas yang dimiliki UMKM "Ameera Hijab" pada tahun 2020 dengan menghitung ROA atau Return On Asset diperoleh nilai aktual sebesar $37 \%$ lebih tinggi dari nilai standar yakni 5,85\% menunjukkan bahwa UMKM "Ameera Hijab" mampu menghasilkan atau memperoleh keuntungan di atas nilai standar atau mempunyai profitabilitas tinggi atau profitabel sesuai dengan penelitian (Saefullah, 2018) bahwa semakin tinggi rasio ROA yang dimiliki oleh suatu perusahaan berarti perusahaan tersebut mempunyai kemampuan menghasilkan laba dengan baik.

3. Rasio solvabilitas yang dimiliki UMKM “Ameera Hijab" pada tahun 2020 dengan menghitung rasio total utang terhadap total aset atau debt to asset ratio diperoleh nilai aktual sebesar 0 yang jelas lebih rendah dari nilai standar yakni $35 \%$ menunjukkan solvabilitas rendah atau solvabel itu dikarenakan UMKM "Ameera Hijab" tidak memiliki utang jangka pangjang dan utang jangka pendek dalam pengelolaan usahanya. Sesuai dengan teori yang dikemukana (Hanafi, 2016) bahwa semakin tinggi rasio debt to asset ratio berarti perusahaan semakin beresiko atau tidak baik karena perusahaan semakin tidak mempunyai kemampuan untuk memenuhi kewajiban jangka panjang dan jangka pendeknya.

\section{PENUTUP}

Simpulan

1. Kesehatan keuangan UMKM Ameera Hijab di masa pandemi Covid-19 pada tahun 2020 dalam kondisi baik ditinjau dari nilai rasio likuiditas sebesar tak terhingga.

2. Kesehatan keuangan UMKM Ameera Hijab di masa pandemi Covid-19 pada tahun 2020 dalam kondisi baik ditinjau dari nilai rasio profitabilitas sebesar $37 \%$.

3. Kesehatan keuangan UMKM Ameera Hijab di masa pandemi Covid-19 pada tahun 2020 dalam kondisi baik ditinjau dari nilai rasio solvabilitas $0 \%$. 
Saran

Bagi peneliti selanjutnya sebaiknya menggunakan rasio keuangan selain yang telah digunakan peneliti untuk melengkapi hasil penelitian terhadap UMKM Ameera Hijab.

\section{DAFTAR PUSTAKA}

apolonaris Felix Erakipia, H. G. (2016). Analisis Laporan Keuangan Sebagai Dasar Penilaian Kinerja Keuangan Pada Umkm Amungme Dan Kamoro.

Dewi, M. (2017). Penggunaan Analisis Rasio Likuiditas Dan Solvabilitas Untuk Mengukur Kinerja Keuangan Di Pt.Aneka Tambang Tbk. Penelitian Ekonomi Akuntansi, 1(2), 102-112.

Https://Ejurnalunsam.Id/Index.Php/Jensi/Issu e/View/46

Hanafi, M. M. (2016). Manajemen Keuangan (2nd Ed.). Bpfe-Yogyakarta.

Martina. (2019). Mengenal Rasio Rentabilitas
(Probability Ratio) Dan Cara

Menghitungnya.

Https://Ukirama.Com/Blogs/Mengenal-

Rasio-Rentabilitas-Probability-Ratio-Dan-

Cara-Menghitungnya.

Saefullah, E. Dkk. (2018). Analisis Kinerja Keuangan Menggunakan Rasio Profitabilitas Pada Pt Xl Axiata, Tbk Dan Pt Indosat Ooredoo,Tbk Periode 2011-2016 Yang Terdaftar Di Bursa Efek Indonesia. 4.

Sari, D. A., Nuringwahyu, S., Zunaida, D., Mayjend, J., No, H., Telp, M., Universitas, L., Malang, I., Mayjend, J., \& No, H. (2019). Kesehatan Keuangan ( Studi Pada Pt. Semen Indonesia, Tbk Yang Terdaftar Di Bursa Efek Indonesia) Analisis Rasio Keuangan Rasio Likuiditas. 8(2), 100-104.

Yuwono, J. (2020). Berkat Inovasi, Pedagang Hijab Dapat Berkah di Tengah Pandemi. Https://Economy.Okezone.Com/Read/2020/1 0/04/455/2288256/Berkat-Inovasi-PedagangHijab-Dapat-Berkah-Di-Tengah-Pandemi. 